Historic, Archive Document

Do not assume content reflects current scientific knowledge, policies, or practices. 


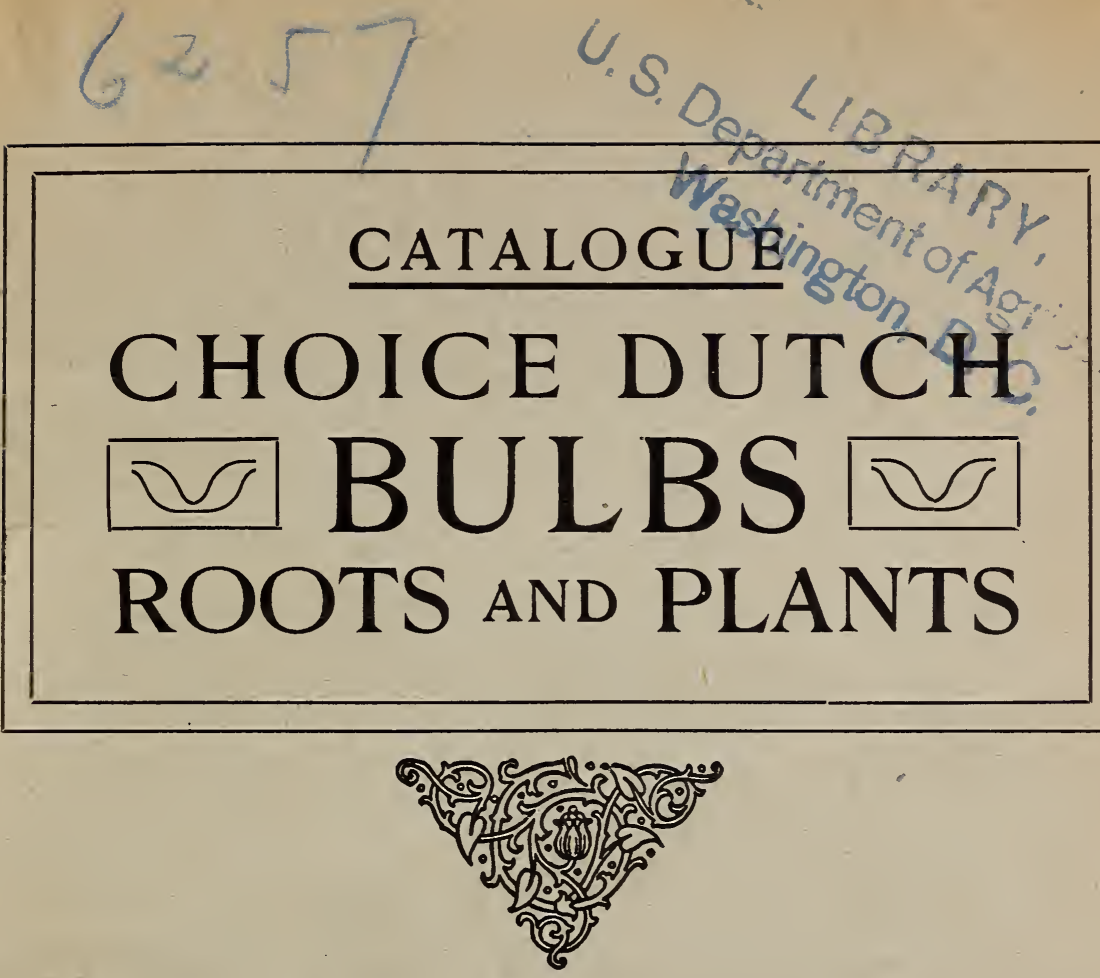

SPRING, 1905

GROWN AND CAREFULLY SELECTED BY HULSEBOSCH BROS. Address for the United
States and Canada ENGLEWOOD, N.J. 


\section{GENERAL DIRECTIONS TO CORRESPONDENTS}

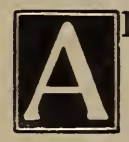

LL BULBS, ROOTS AND PLANTS QUOTED

AT RIECE OR DOZEN RATES IN THIS

CATALOGUE ARE NET, FREE DELIVERED AT DESTINATION OR AT NEAREST EXPRESS OFFICE. LARGER QUANTITIES BY EXPRESS AT PURCHASER'S ACCOUNT.

DISCOUNT. WE ALLOW 10 PER CENT. FOR CASH WITH ORDER.

NOT LESS THAN 6 BULBS, ROOTS OR PLANTS OF ONE NAMED VARIETY WILL BE QUOTED AT 12 RATE, 25 AT 100 RATE, AND 250 AT 1000 RATE.

WE GUARANTEE SAFE ARRIVAL OF THE GOODS.

ALL PRICES ARE SUBJECT TO CHANGE.

\section{H ULSEBOSCH B ROTHERS ENGLEWOOD, N. J.}




\title{
Select List of Bulbs and Plants
}

25 at 100 , and 250 at 1000 rates.

\section{Agapanthus}

\author{
(African Lily)
}

This is one of the handsomest plants in cultivation. It is naturally a summer-blooming plant, and admirably suited for parlor or conservatory decorations, being very attractive, with its glossy green foliage and large trusses of magnificent bloom.

A. umbellatus, fine blue, extra, 20c. each; $\$ 2.00$ per doz.

A. umbellatus albus monstrosus, large white, $25 \mathrm{c}$, each; $\$ 2.50$ per doz.

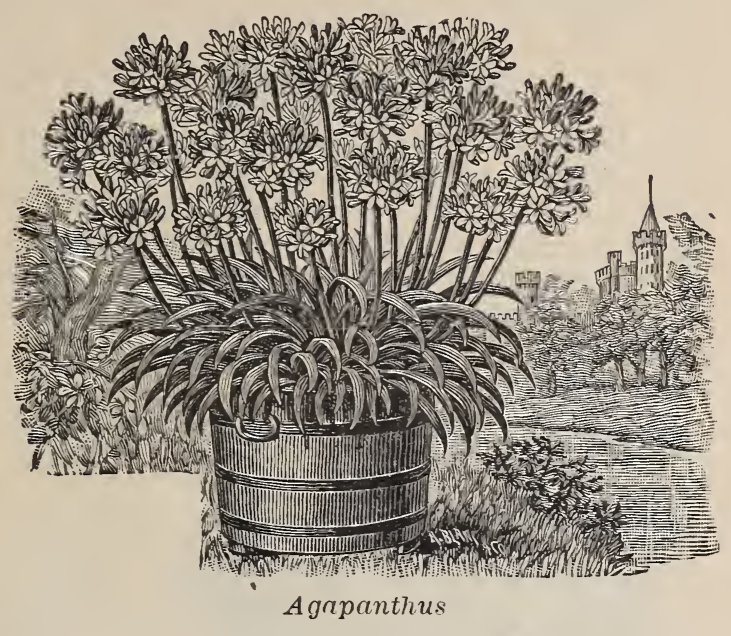

\section{Amaryllis (Species of Hippeastrum)}

It is impossible to name a more magnificent genus of bulbous plants than these. They are of the easiest possible culture and require but little care to throw up their beautiful trumpet-shaped flowers of the richest colors, from crimson to nearly pure white, lined and flushed with yellow, light rose, vermilion, dark red and purple. We recommend them with the utmost confidence for the decoration of conservatory or drawing room.

Belladona major, large, dark rose and white, $20 \mathrm{c}$. each, $\$ 2.00$ per doz.

Equestre, fine bright orange, margined white, with a green star, $15 \mathrm{c}$. each, $\$ 1.50$ per doz.

Formosissima (Jacobean Lily), grand dark scarlet, shaded with numerous golden dots. It forces well and is certainly a real gem for frame and greenhouse, 10c. each, $\$ 1.00$ per doz. Johnsoni grandiflora, red and white striped, large flowering, 25c. each, $\$ 2.50$ per doz.

Longifolia (Crinum capense) fl. alba; very beautiful, free blooming and large, 25c. each, $\$ 2.50$ per doz.

Longifolia (Crinum capense) fl. rosea; large blooms, 25c. each, $\$ 2.50$ per doz.

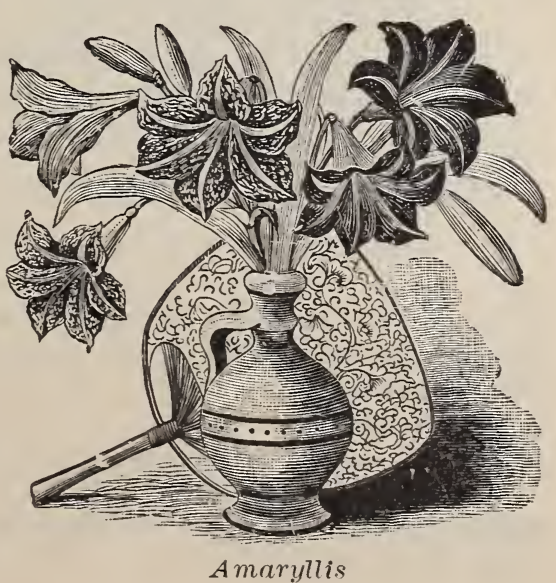

A maryllis 


\section{AMARYLLIS-Continued}

Seedings of Hippeastrum, in best shapes and colors, 30c. each, $\$ 3.00$ per doz. Vittata, beautiful clear white and red striped hybrids, mixed, $40 \mathrm{c}$. each, $\$ 4.00$ per doz.

\section{Anemones}

Anemones are a highly ornamental class of easily cultivated, hardy bulbous roots, with large flowers of nearly all shades and colors, which bloom in spring and early summer when planted in succession from autumn to May. They grow and flower well in any moist, fertile soil, planted $2 \frac{1}{2}$ inches deep and 4 to 5 inches apart.

\section{Anemone coronaria flore pleno}

Very best mixed, all colors, finest quality, first size per $1000, \$ 7.00 ; 20 \mathrm{c}$. per doz., $\$ 1.50$ per 100.

Anemone coronaria fl. simplex

Very best mixed, scarlet, $20 \mathrm{c}$. per doz., $\$ 1.50$ per 100.

Very best mixed, all colors, 16c. per doz., $\$ 1.20$ per 100.

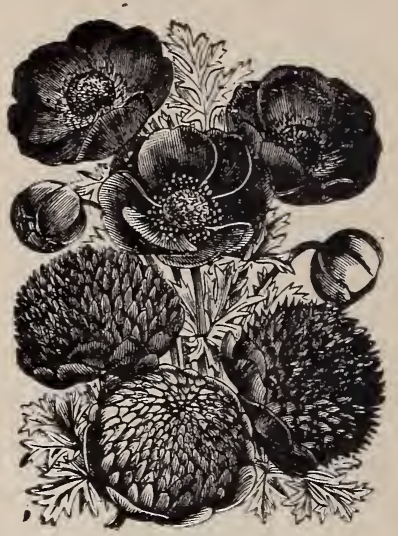

Anemone

\section{Various Anemones}

Japonica alba (Whirlwind), new, very large, 8c. each, 80c. per doz., $\$ 5.00$ per 100 .

“ “ (Honorine Jobert), 8c. each, 80c. per doz., $\$ 5.00$ per 100.

“ rosea (elegans), 8c. each, 80c. per doz., $\$ 5.00$ per 100.

“ rubra (type), 8c. each, 80c. per doz., $\$ 5.00$ per 100 .

“Queen Charlotte, pink, 10c. each, $\$ 1.00$ per doz., $\$ 6.00$ per 100 .

“Pulsatilla vernalis, light blue, 10c. each, $\$ 1.00$ per doz., $\$ 6.00$ per 100 .

\section{Begonias-Bulbous Rooted}

We recommend our Begonias as being the finest strain in existence in shape and colors. Many of the individual flowers will attain, if proper attention be given to the plants, over 4 inches in diameter. We are sure they will give entire satisfaction.

Double, in scarlet, white, pink or yellow, $12 \mathrm{c}$. each, $\$ 1.20$ per doz., $\$ 10.00$ per 100 .

Double, in very best mixed, 10c. each, $\$ 1.00$ per doz., $\$ 8.00$ per 100 .

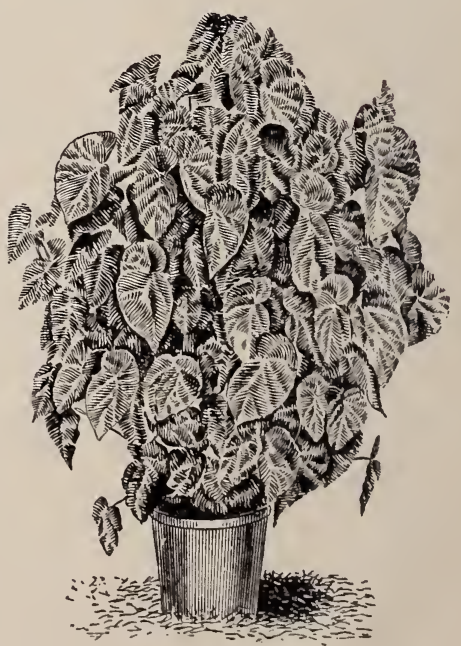

Begonia 


\section{BEGONIAS-Continued}

Single Begonias, $1 \frac{1}{2}$ to $2 \frac{1}{2}$ inches in diameter-in pink and rosy shades, $7 \mathrm{c}$. each, 70c. per doz., $\$ 5.00$ per 100 .

In dark red shades, 7c. each, 70c. per doz., $\$ 5.00$ per 100 .

In white shades, 7c. each, 70c. per doz., $\$ 5.00$ per 100 .

In yellow shades, 7c. each, 70c. per doz., \$5.00 per 100 .

Single, all colors, mixed, 6c. each, 60c. per doz., $\$ 4.50$ per 100 .

\section{Large Flowering Dwarf Cannas}

Of these beautiful garden plants we need not say that a few of them should be planted by every lover of flowers; they begin to bloom soon after being planted, and continue until winter. We only grow a few of tried merit, discarding every year the poorer and replacing them with newer and better sorts.

\section{Our Standard Dozen of Twelve Well-tried Varieties.}

Admiral Schley, orange scarlet.

Allemania, dark salmon and golden.

Austria, fine, yellow, with few reddish brown spots.

Crimson Bedder, bright crimson.

Egandale, bronze foliage, soft currant red.

Florence Vaughan, finest of yellows.

J. D. Cabos, bright orange, dark foliage.

Madame Crozy, scarlet, bordered yellow.

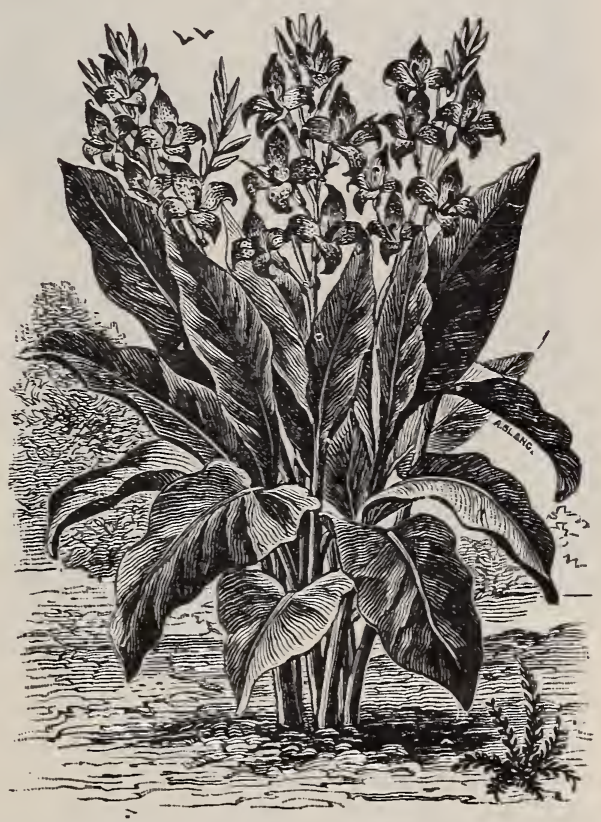

Large Flowering Dwarf Cannas

Paul Marquant, salmon, tinted scarlet.

President McKinley, large scarlet.

Queen Charlotte, scarlet, gold bordered.

West Grove, coral pink.

Any of the above, 8c. each, 80c. per doz., $\$ 5.00$ per 100 .

The whole collection of 12 in 12 sorts. $\$ 1.00$; different sorts of cannas mixed, $\$ 5.00$ per 100 . The above pot-grown after May 1st, 15c. each; $\$ 1.50$ per doz. 


\section{Funkias (Plantation Lily)}

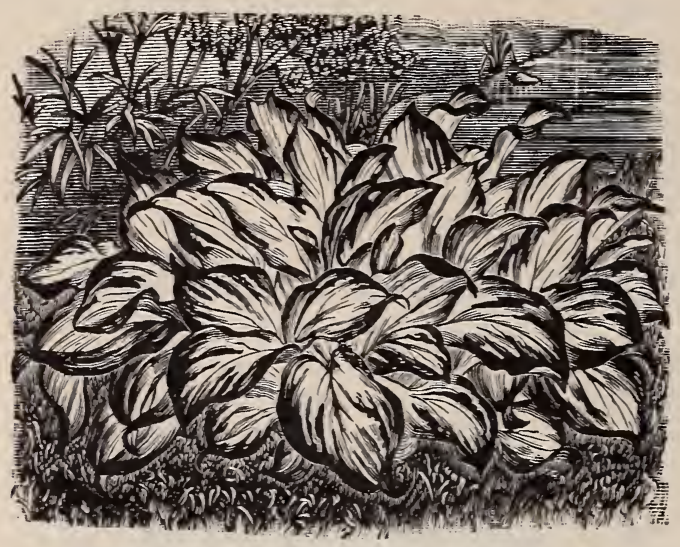

Funkia

Funkias are hardy herbaceous plants, posisessing handsome leaves, the flowers being very delicate both in form and color. Their requirements are few; they grow to perfection in any situation and they will, in a short time, make immense fine-leaved clusters, which flower freely in August.

Cuculbata (Sieboldiana), fine pla n $t$, remarkably graceful foliage, regularly veined and figured; fine lilac flower, 12c. each, $\$ 1.20$ per doz.

Cuculbata albo-marginata, lilac; silver variegated foliage, finest for borders, 8c. each, 80c. per doz.

Cuculbata aurea marmorata, lilac and purplish, gold variegated foliage, $8 \mathrm{c}$. each; 80c. per doz.

Fortunei, light blue, rigid, glaucous foliage, $15 \mathrm{c}$. each, $\$ 1.50$ per doz.

Subcordata grandiflora, large pure white lily shaped, immense flowers and leaves, $15 \mathrm{c}$. each, $\$ 1.40$ per doz.

Univittata, light lilac, green foliage, edged white, $8 \mathrm{c}$. each; 80c. per doz.; 6 in 6 finest named $\nabla$ arieties, $50 \mathrm{c}$.

\section{Gladiolus}

\section{Home-Grown Bulbs. In the very Best Sorts only}

The gladioli are certainly the most desirable of our summer-blooming bulbs, throwing up their tall spikes of brilliant and showy flowers to a height of two feet and more. The flowers are of almost every desirable color; scarlet, crimson, purple, white, rose, yellow and white, blotched and striped in the most beautiful manner. They may all be grown out-of-doors in any common garden soil; are admirably adapted for grouping among evergreen plants, and are invaluable as cut flowers for bouquets and vases, every spike coming to full development to the last bud when placed in water.

Augusta, white, 6c. each; 60c. per doz.; $\$ 4.50$ per 100 .

Brenchleyensis, vermilion-scarlet, 6c. each; 25c. per doz.; $\$ 1.60$ per 100.

Columbia, orange-scarlet, 5c. each; 40c. per doz.; $\$ 2.00$ per 100 .

Eugene Scribe, perfect, tender rose, 6c. each.; 60c. per doz.; $\$ 4.00$ per 100 .

Florida, dark red, 6c. each; 60c. per doz.; $\$ 4.00$ per 100.

Grand Rouge, rery large flowers, bright scarlet, 8c. each; 80c. per doz.; $\$ 6.00$

per 100 .

Isaac Buchanan, very fine yellow, 6c. each; 60c. per doz.; $\$ 4.00$ per 100 .

Lamarck, cherry, red and white, 6c. each; 60c. per doz.; \$4.00 per 100. 


\section{GLADIOLUS-Continued}

May, white and crimson, 5c. each ;

50c. per doz.; $\$ 3.50$ per 100 .

Mme. Moneret, delicate rose, extra, 5c. each; 30c. per doz.; $\$ 1.60$ per 100 .

Napoleon III., bright scarlet, white line in each petal, $5 c$. each; 50c. per doz.; $\$ 2.00$ per 100.

Shakespeare, white, slightly suffused with carmine-rose, $10 \mathrm{c}$. each; $\$ 1.00$ per doz.; $\$ 6.00$ per 100.

Al! Scarlet Varieties, mixed, $5 c$. each; 25c. per doz.; $\$ 1.50$ per 100.

All Pink Varieties, mixed, $5 \mathrm{c}$. each; 30c. per doz.; $\$ 2.00$ per 100.

All Yellow and Orange, mixed, 5c. each; 50c. per doz.; $\$ 3.00$ per 100 .

All Striped and Variegated, mixed, 6c. each; 40c. per doz.; $\$ 3.00$ per 100 .

All white and light colors, $6 \mathrm{c}$. each; 35c. per doz.; $\$ 2.50$ per 100.

American Hybrids, all colors, $\$ 12.00$ per 1,000 ; 5c. each; 30 c. per doz.; $\$ 3.00$ per 100 .

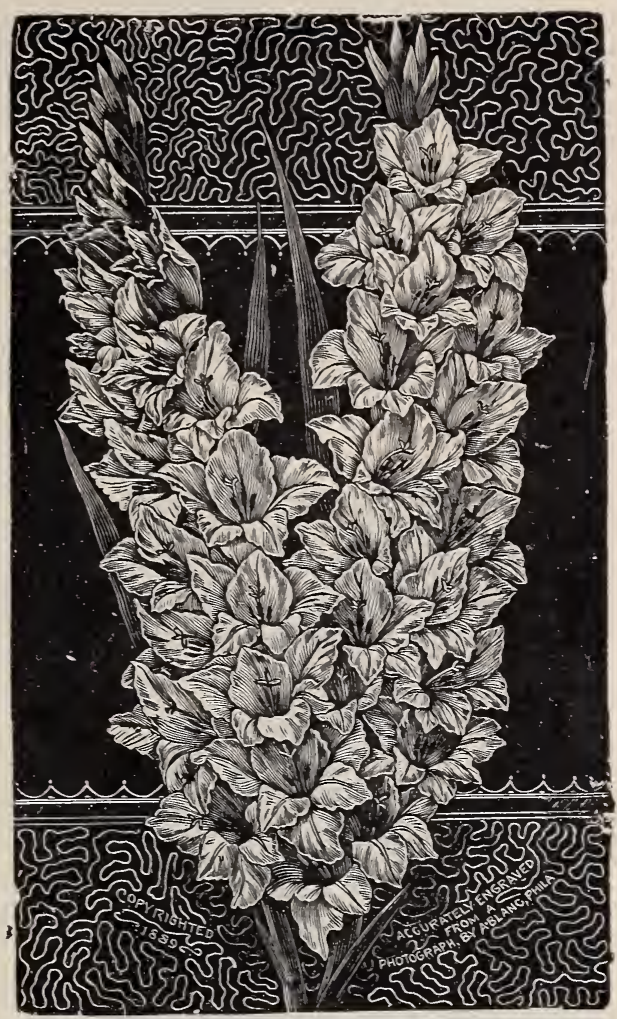

Gladiolus

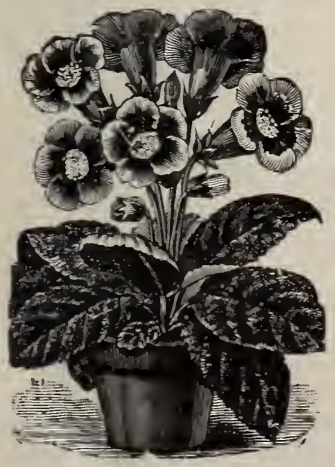

Gloxinia

\section{Gloxinias}

Most charming stove gesneraceous plants of dwarf habit, but producing large and splendid blooms in the greatest abundance under the commonest culture. Bloom continuously for months, and by starting at in tervals, a succession of their splendid flowers may be had nearly the whole year round. They thrive best in sandy peat or loam, and require a plentiful supply of water.

Fine Seedlings, in all colors, mixed, $\$ 6.00$ per 100 ; $\$ 1.00$ per doz.; 10c. each. 


\section{Hemerocallis (Day Lily)}

These beautiful perennials are perfectly hardy, and produce in June and July a profusion of orange and clear yellow lily-like flowers in large clusters. When once planted they will take care of themselves and certainly give entire satisfaction.

Distichia fl. pl., double orange-crimson, 8c. each; 80c. per doz.

Flava, sweet-scented, very nice, 6c. each; 60c. per doz.

Fulva, bronze-orange, changing to crimson; strong grower, 6c. each; 60c. per doz.

“ fol. var., beautiful, 10c.; $\$ 1.00$ per doz.

Kwanso fl. pl., large double, orange-red, with crimson netting, splendid, 10c. each; $\$ 1.00$ per doz.

Thunbergia, beautiful yellow, 6c. each; 60c. per doz.

Hemerocallis, all sorts mixed, 5c. each; 50c. per doz.

\section{Irises}

IRIS GERMANICA. No hardy border flowers are more showy or have a more pleasing appearance than the Iris Germanica. They produce immense large flowers, of the most distinct colors. They are very fit for rockwork or any other garden decorations, and are remarkable as one of the very few excellent.hardy flowers that successfully resist the dust and smoke of even the largest cities.

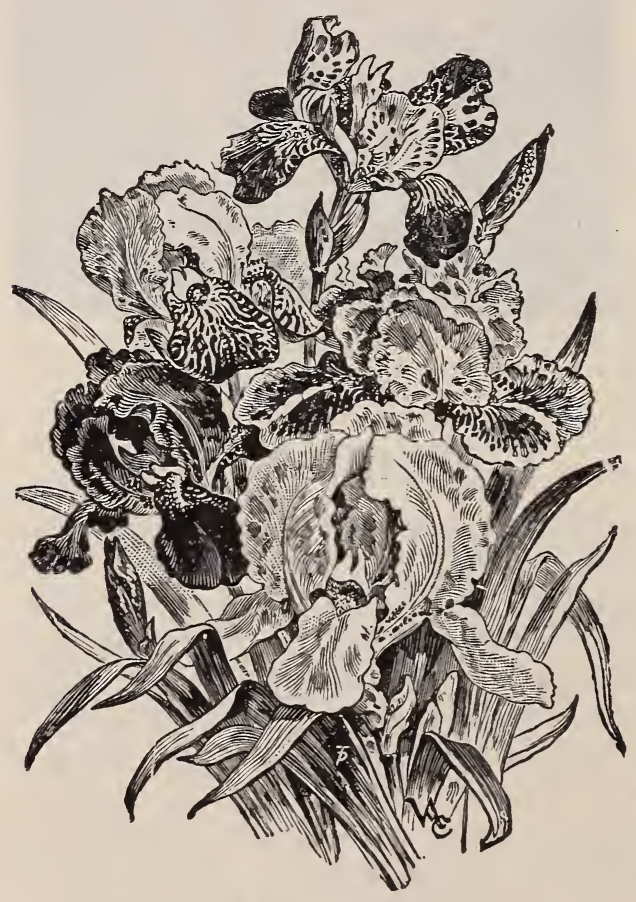

Iris Germanica
100 in 10 finest named sorts, strong roots........\$3 00

50 in 10 finest named sorts, strong roots.........2 200

12 in 12 finest named sorts, strong roots.......... 60 Very fine mixed, various sorts and colors, $1,000, \$ 6 ; 100, \$ 1$; doz., 20 c.

IRIS KAEMPFERI is perhaps the very finest of the various Iris groups existing, being perfectly hardy, and flowering in the greatest profusion during June and July in most beautiful variegations.

100 in 10 finest named sorts, strong roots.......\$7 00

50 in 10 finest named sorts, strong roots.........4 400

25 in 12 finest named sorts, strong roots.........2 40

12 in 12 finest named sorts, strong roots.......... 130

6 in 6 finest named sorts, strong roots......... 80

Very fine varieties, all colors mixed, 100, $\$ 6.00$; doz., 70c.; each, 7c. 


\section{Lilium}

Lilies are the most desirable hardy bulbous-rooted plants in cultivation. In pots or anywhere in the open ground they are superb and produce a most charming effect. They should be planted from October to May, in good, rich, loamy soil, about four inches deep. After planting they require but little care, and should not be taken up for several years, as they bloom more freely than if taken up annually.

100 in 10 best named bor. var................\$10 00

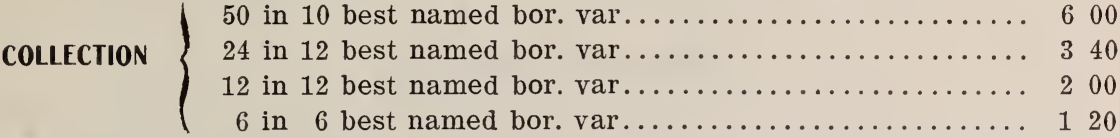

Mixed border varieties, $\$ 1.00$ per doz., $\$ 7.00$ per 100 .

Atrosanguineum, dark red, 16c. each, $\$ 1.50$ per doz., $\$ 10.00$ per 100 .

Auratum (Queen of Lilies), pure ivory-white, with a beautiful golden band through the center of each petal and dotted with velvety brownish crimson spots, very fragrant, $15 \mathrm{c}$. each, $\$ 1.50$ per doz., $\$ 10.00$ per 100 .

Longiflorum, 9 to 10 inches in circum. ference, $16 \mathrm{c}$. each, $\$ 1.60$ per doz., $\$ 8.00$ per 100 .

Melpomene, large, rich, blood-crimson, spotted, 14c. each, $\$ 1.40$ per doz., $\$ 8.00$ per 100 .

Speciosum album, pure alabaster white flowers, 15c. each, $\$ 1.50$ per doz., $\$ 8.00$ per 100 .

Speciosum album (Crown Princess), pure white, very free blooming, sometimes 50 blooms on one plant, 20c. each, $\$ 2.00$ per doz., $\$ 12.00$ per 100.

Speciosum roseum, white, suffused and spotted rosy, $15 \mathrm{c}$. each, $\$ 1.50$ per doz., $\$ 8.00$ per 100 .

Speciosum rubrum, white, suffused and spotted crimson, free flowering, $15 \mathrm{c}$.

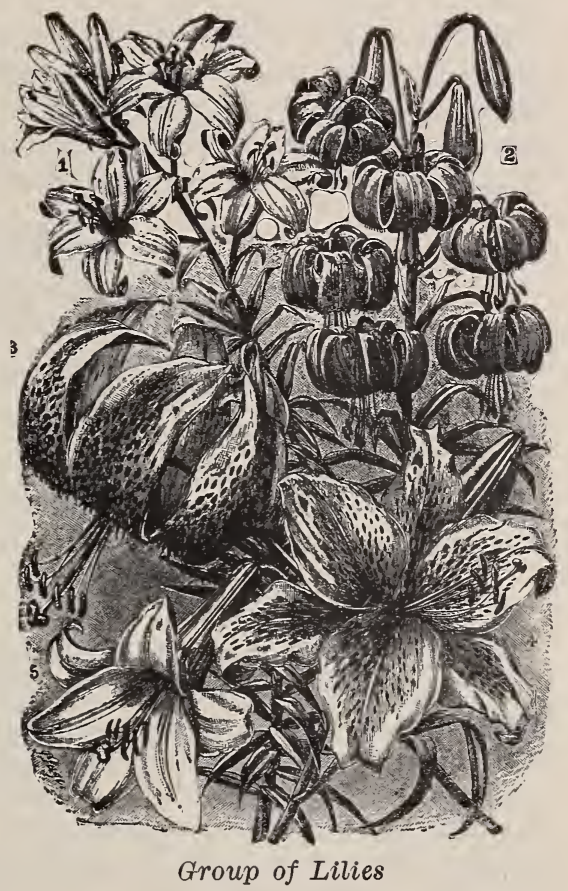
each, $\$ 1.50$ per doz., $\$ 8.00$ per 100 .

Speciosum punctatum, frosted white, rich pink spots, $20 \mathrm{c}$. each, $\$ 2.00$ per doz., $\$ 10.00$ per 100 .

Tigrinum (The Tiger Lily), rich, orange-red and black spots, 8c. each, 80c. per doz., $\$ 4.00$ per 100 .

Tigrinum Fortunei, rich scarlet and black, 10c. each, $\$ 1.00$ per doz., $\$ 5.00$ per 100 . “ fl. pleno (Double Tiger Lily), immense flowers, deep scarlet, large black spots, beautiful, 10c. each, $\$ 1.00$ per doz., $\$ 6.00$ per 100 . 


\section{LILIUM-Continued}

Tigrinum splendens (Leopoldi), very fine, tall rich scarlet and black spotted blooms, 10c. each, $\$ 1.00$ per doz., $\$ 5.00$ per 100 .

Umbellatum erectum, carmine, scarlet and yellow, $10 \mathrm{c}$. each, $\$ 1.00$ per doz., $\$ 6.00$ per 100.

“

incomparabilis, dark crimson and orange, 10c. each, $\$ 1.00$ per doz., $\$ 6.00$ per 100 .

“ incomparable monstrosum, very large and distinct, 14c. each, $\$ 1.40$ per doz., $\$ 8.00$ per 100 .

\section{Montbretias}

A very beautiful class of bulbous-rooted plants. They are related to the gladioli, which they closely resemble in habit of growth. They are of the easiest culture and succeed admirably in the open ground like other bulbs; flowers are borne in branches and spikes 2 to 3 feet high, with from 40 to 50 flowers on each stem, which make them very showy and attractive. Very recommendable.

CROCOSMIAEFLORA, scarlet and golden yellow, 4c. each, 30c. per doz., $\$ 2.00$ per 10 . POTTSI, fine, golden orange-scarlet extra, 4c. each, 30c. per doz., $\$ 2.00$ per 100 . ROSEA, soft rose-red and yellow, very fine, 4c. each, 30c. per doz., $\$ 2.00$ per 100 . AUREA, extra yellow, 6c. each, 60c. per doz., $\$ 4.00$ per 100 .

\section{Oxalis}

A splendid class of hardy bulbous-rooted plants, with brilliantly colorerl flowers and dark, pretty foliage, suitable for either greenhouse decoration, rock. work or rustic baskets out of doors.

Arborea alba, white, free-flowering, from June until winter, 5c. each, 50c. per doz., $\$ 3.00$ per 100 .

“ coccinea, red, 5c. each, 50c. per doz., $\$ 3.00$ per 100.

“ tricolor, red, violet and white, 5c. each, 50c. per doz., $\$ 3.00$ per 100

Different Sorts, mixed, 14c. per doz., 70c. per 100.

\section{Ranunculus}

Among dwarf flowers the Ranunculus is unrivaled for its lovely form and its brilliant and attractive colors-white, crimson, yellow, purple and black. They present nearly a round of the most gorgeous hues combined with compactness and symmetry unequaled in any other flower. The individual flowers are about two inches in diameter, beautifully imbricated, and as full and double as the finest camellia or rose. Their effect is truly magnificent in the spring flower garden, and they are very suitable for cut flowers. They must be planted in a moist and fertile soil, about two inches deep and three to four inches apart.

Double Persian Ranunculus. In very fine mixture, all colors, 12c. per doz., 60c. per $100, \$ 4.00$ per 1000 .

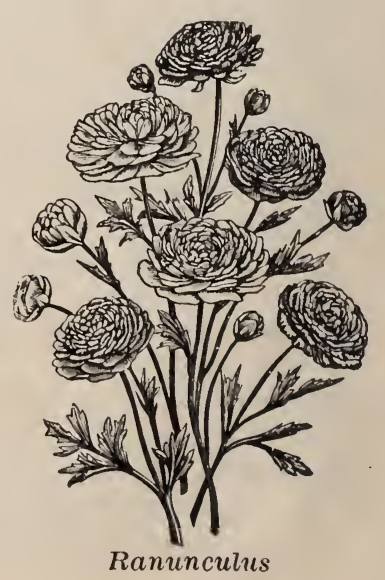




\section{RANUNCULUS-Continued}

Giant Double French Ranunculus (very free bloom.ing). all colors, 12c. per doz., 60c. per 100, $\$ 4.00$ per 1000 .

Double Turban Ranunculus. In very best mixture, all colors, first quality, $14 \mathrm{c}$. per doz., S0c. per 100, $\$ 6.00$ per 1000 .

\section{Japan Maples}

Acer sanguineum Seigen, blood-red, coloring in Spring.

" sariguineum, blood-red, small leaves.

" atrosanguineum dissectum, deep maroon.

" roseum, margined with crimson,

" scolopendufolium rubrum, dark red, fine narrow leaflets.

"Oshiu Shidara, green, margined with maroon.

" aureum, yellow.

“ riticulatum, green and yellow.

" aureum pictum.

" rosa marginatis, green, rose margined.

" versicolor, crimson, white and green.

“ atropurpureum variegatum, dark maroon and white.

Fine young shrubs, $1 \frac{1}{2}$ to 2 feet, any of the above, each $\$ 1.00$;

6 in 6 sorts, $\$ 5.00 ; 12$ in 12 sorts, $\$ 9.00$.

\section{Azaleas}

Azalea mollis (Hardy). Without names, 8 to 15 buds, $\$ 5.00$ per doz., 50c. each; 15 to 20 buds, $\$ 7.00$ per doz., 70c. each.

Azalea ponticum (Hardy). 12 in 6 fine named varieties, 8 to 10 buds, $\$ 6.00 ; 6$ in 6 fine named varieties, 8 to 10 buds, $\$ 3.00$; without names, 8 to 10 buds, $\$ 5.00$ per doz., 50c. each; without names, 10 to 15 buds, $\$ 6.00$ per doz., $70 \mathrm{c}$. each.

\section{Clematis (Virgin Bower)}

Three years old, in various fine named varieties. $\$ 22.00$ per $100, \$ 3.00$ per doz., 30c. each.

C. paniculata gr. fl. $\$ 20.00$ per $100, \$ 2.60$ per doz., 26c. each.

\section{Hybrid Roses, Dormant (Low Budded)}

Large, two years old, of the finest sorts, such as UIrich Brunner, Magna Charta, General Jacqueminot, La France, Perle La Blanche, Alfred Colomb, Mme. Gab. Luizet, Mme. Plantier, Persian Yellow, Prince Camille de Rohan, Mrs. John Laing, Mabel Morrison.

100 in 10 sorts, $\$ 13.00 ; 12$ in 12 sorts, $\$ 2.00 ; 6$ in 6 sorts, $\$ 1.00 ; 20$ c. each.

Crimson Rambler, 2 years old, field-grown, very strong, 30c. each, $\$ 3.00$ per doz., $\$ 20.00$ per 100 .

Yellow Rambler, 2 years old, field-grown, very strong, 30c. each, $\$ 3.00$ per doz., $\$ 20.00$ per 100 .

White Rambler, 2 years old, field-grown, very strong, 30c. each, $\$ 3.00$ per doz., $\$ 20.00$ per 100 .

Rosa rugosa, Red, strong, field-grown, very strong, 20c. each, $\$ 2.00$ per doz., $\$ 13.00$ per 100 .

Rosa rugosa, White, strong, field-grown, very strong, 20c. each, $\$ 2.00$ per doz., $\$ 13.00$ per 100 . 


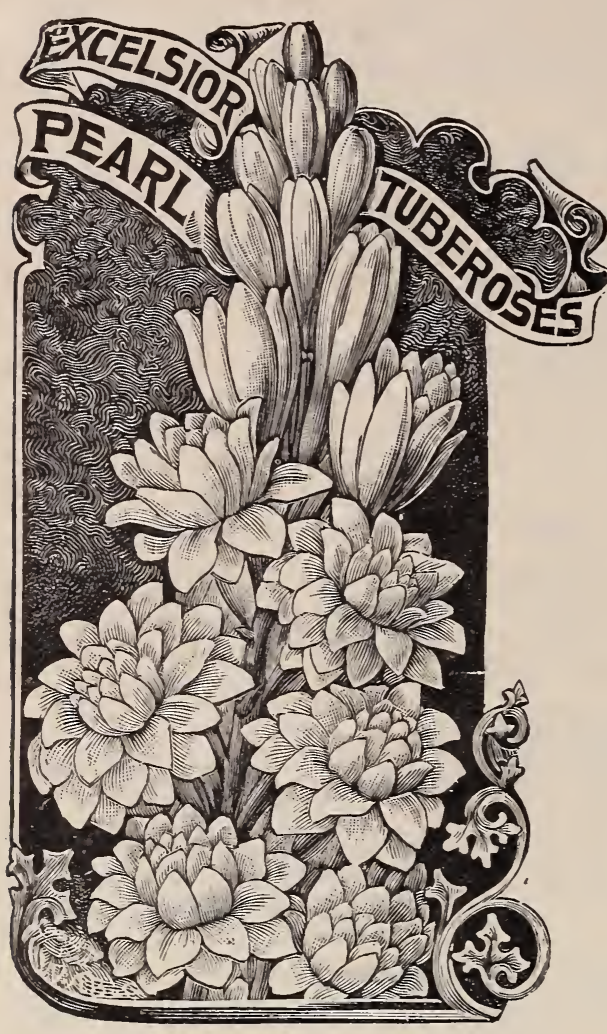

\section{Rhododendrons}

HARDY HYBRIDS

4 to 8 buds, height 1 foot, $\$ 1.00$ each; $\$ 10.00$ per doz.

8 to 12 buds, height $1 \frac{1}{2}$ feet, $\$ 1.50$ each; $\$ 15.00$ per doz.

12 to 20 buds, height 2 feet, $\$ 2.00$ each; $\$ 20.00$ per doz.

\section{Tuberoses}

\section{A1 BIG BULBS, SURE TO BLOOM}

The Pearl, $\$ 8.00$ per $1000 ; \$ 1.30$ per 100 ; 30c. per doz.

The Pearl, monster size, $\$ 12.00$ per $1000 ; \$ 1.60$ per $100 ; 40 \mathrm{c}$. per doz.

\section{Spiræa (Hoteia)}

Astilboides, new species of remarkable merit, pure white, $15 \mathrm{c}$. each; $\$ 1.50$ per doz.

Compacta multiflora, new, pure white, 15c. each; $\$ 1.50$ per doz.

Japonica (Astilbe), pure white, $15 \mathrm{c}$. each; $\$ 1.50$ per doz.

Japonica (Astilbe) aurea reticulata, golden striped foliage, $15 \mathrm{c}$. each; $\$ 1.50$ per doz.

Palmata, scarlet, very fine, $15 \mathrm{c}$. each; $\$ 1.50$ per doz.

Palmata alba, 20c. each; $\$ 2.00$ per doz.

\section{Miscellaneous Bulbs and Plants}

CALLA Richardia alba maculata, pure white flowers, with beautiful violet shades inside, fine spotted foliage; a grand bedder; large bulbs, $10 \mathrm{c}$. each; $\$ 1.00$ per doz.; $\$ 6.00$ per 100 .

\section{CALADIUM ESCULENTUM.}

Monster Bulbs, 11 to 12 inches circumference, $30 \mathrm{c}$. each; $\$ 2.00$ per doz.

First Size, 9 to 11 inches circumference, $14 \mathrm{c}$. each; $\$ 1.40$ per doz.

Second Size, 7 to 9 inches circumference, $12 \mathrm{c}$. each; $\$ 1.20$ per doz.

Third Size, 5 to 7 inches circumference, $10 \mathrm{c}$. each; $80 \mathrm{c}$. per doz. 


\section{MISCELLANEOUS BULBS AND PLANTS-Continued}

CINNAMON Vine Roots, first selected, 5c. each; 50c. per doz.; $\$ 4.00$ per 100 . CONVALLARIA polygonata (Solomon's Seal), 8c. each; 60c. per doz.

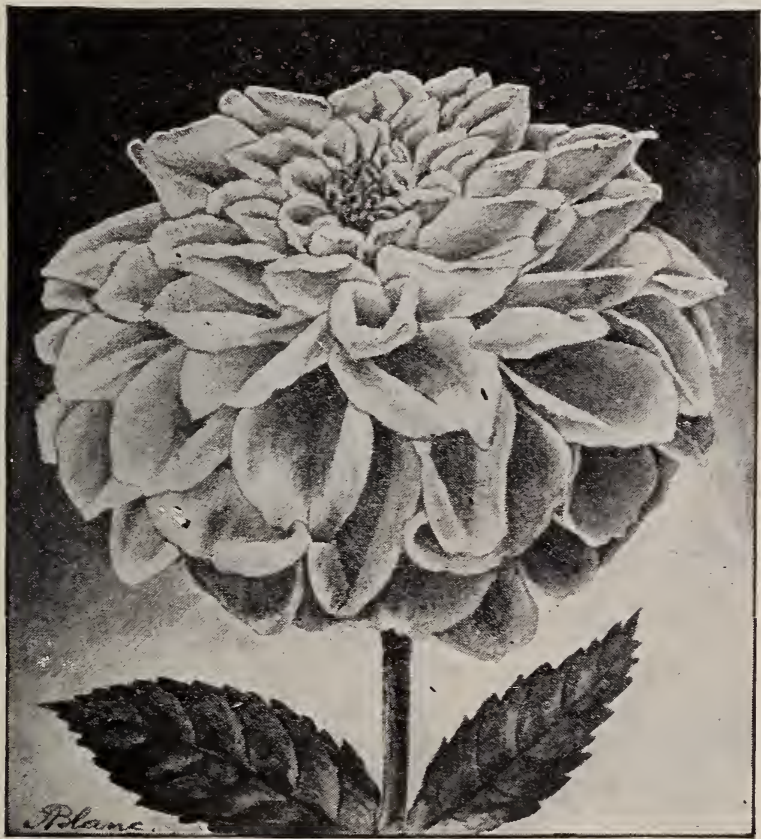

Dahlia

\section{DAHLIAS, Large Flowering Sorts.}

12 in 12 field-grown clumps, $\$ 2.00$. 6 in 6 field-grown clumps, $\$ 1.00$.

Mixed, 15c. each; $\$ 1.50$ per doz; $\$ 10.00$ per 100 .

DAHLIAS, Pompon Varieties.

12 in 12 field-grown clumps, $\$ 2.00$. 6 in 6 field-grown clumps, $\$ 1.00$.

Mixed, 15c. each; $\$ 1.50$ per doz.; $\$ 10.00$ per 100 .

DAHLIAS, Cactus Varieties.

12 in 12 field-grown clumps, $\$ 2.00$. 6 in 6 field-grown clumps, $\$ 1.00$.

Mixed, 15c. each; $\$ 1.50$ per doz; $\$ 10.00$ per 100 .

DIELYTRA spectabilis (Bleeding Heart), 10c. each; $\$ 1.00$ per doz.; $\$ 7.00$ per 100 . GALTONIA Hyacinthus candicans, 6c. each; 60c. per doz.; $\$ 3.00$ per 100 . MADEIRA VINE Roots, 4c. each; 40c. per doz.; $\$ 3.00$ per 100. 


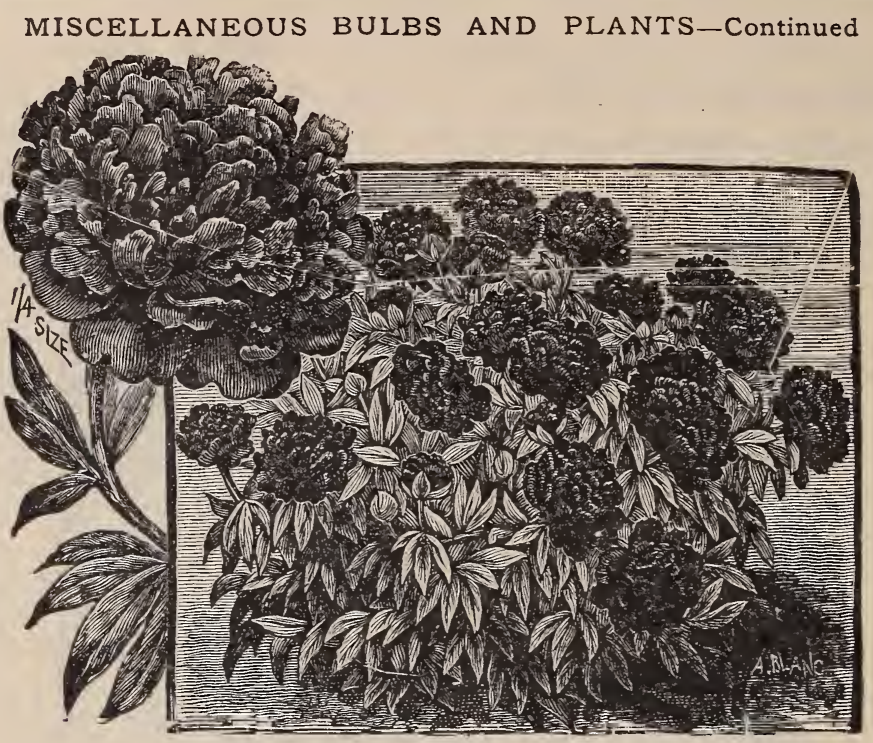

\section{Poeonias}

PAEONIA officinalis fl. pl., double crimson, early, 12c. each, $\$ 1.20$ per doz." $\$ 7.00$ ver 100 .

\begin{tabular}{|c|c|c|c|}
\hline & “؛ & “ & $\begin{array}{l}\text { double rose, early, 15c. each, } \$ 1.50 \text { per doz., } \$ 13.00 \\
\text { per } 100 \text {. }\end{array}$ \\
\hline & “ & “ & double, white, 35c. each, $\$ 3.50$ per doz., $\$ 30.00$ per 100 . \\
\hline & s fl. & 1. pl., & $\begin{array}{l}50 \text { in } 50 \text { named sorts, } \$ 30.00 ; 25 \text { in } 25 \text { named sorts, } \\
\$ 15.00 ; 12 \text { in } 12 \text { named sorts, } \$ 8.00 ; 6 \text { in } 6 \text { named } \\
\text { sorts, } \$ 4.00 \text {. }\end{array}$ \\
\hline & “ & “" & $\begin{array}{l}\text { in finest named sorts, mixed, } 12 \mathrm{c} \text {. each, } \$ 1.20 \text { per doz., } \\
\$ 9.00 \text { per } 100 \text {. }\end{array}$ \\
\hline & “ & “ & double rose, $20 \mathrm{c}$. each, $\$ 2.00$ per doz., $\$ 14.00$ \\
\hline & ". & " & white, $25 \mathrm{c}$. e \\
\hline
\end{tabular}
Our Pronies are very strong rcots, with from 4 to 5 eyes.

\section{Select Japanese Tree Pæonies}

The varieties enumerated below have been selected from a large collection of Japanese varieties, and will be found very interesting.

Abokin. Bright scarlet.

Akashi-jishi. Blush white, shading deeper to center.

Daikugura. Carmine, shading to rose at edges.

Fuji-no-mone. Pure white.

Hakubanryn. Creamy white.

Iwato-kagami. Fine, large pink.

Kamadafuji. Soft pink.
Nishikishima. Bright, soft pink, blush margin.

Ruriban. Dark purple.

Shokikagura. Satiny rose, shading to white on edges.

Shiro-kagura. White, suffused with pink.

Yoyo-no-nomare. Soft rose, the base of petals mottled.

$\$ 1.00$ each. The set of 12 varieties, $\$ 10.00$. Set of 24 varieties, $\$ 18.00$. 


\section{ORDER SHEET for Plants, Bulbs, Etc.}

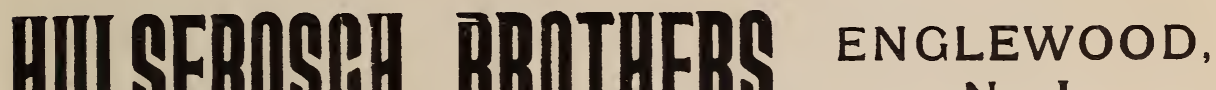 N. J.}

Date,

Name,

P. 0. Order, $\$$

Post Office,

Express Office, ( $\left.\begin{array}{c}\text { If different } \\ \text { from P. O. }\end{array}\right)$

Check

County,

State,

Forwarded by ( $\left.\begin{array}{l}\text { State whether wanted by } \\ \text { Mall, Express or Freight. }\end{array}\right)$

AMOUNT INCLOSED:

Express M. 0.

Poatage Stamps

Total, $\$$ 


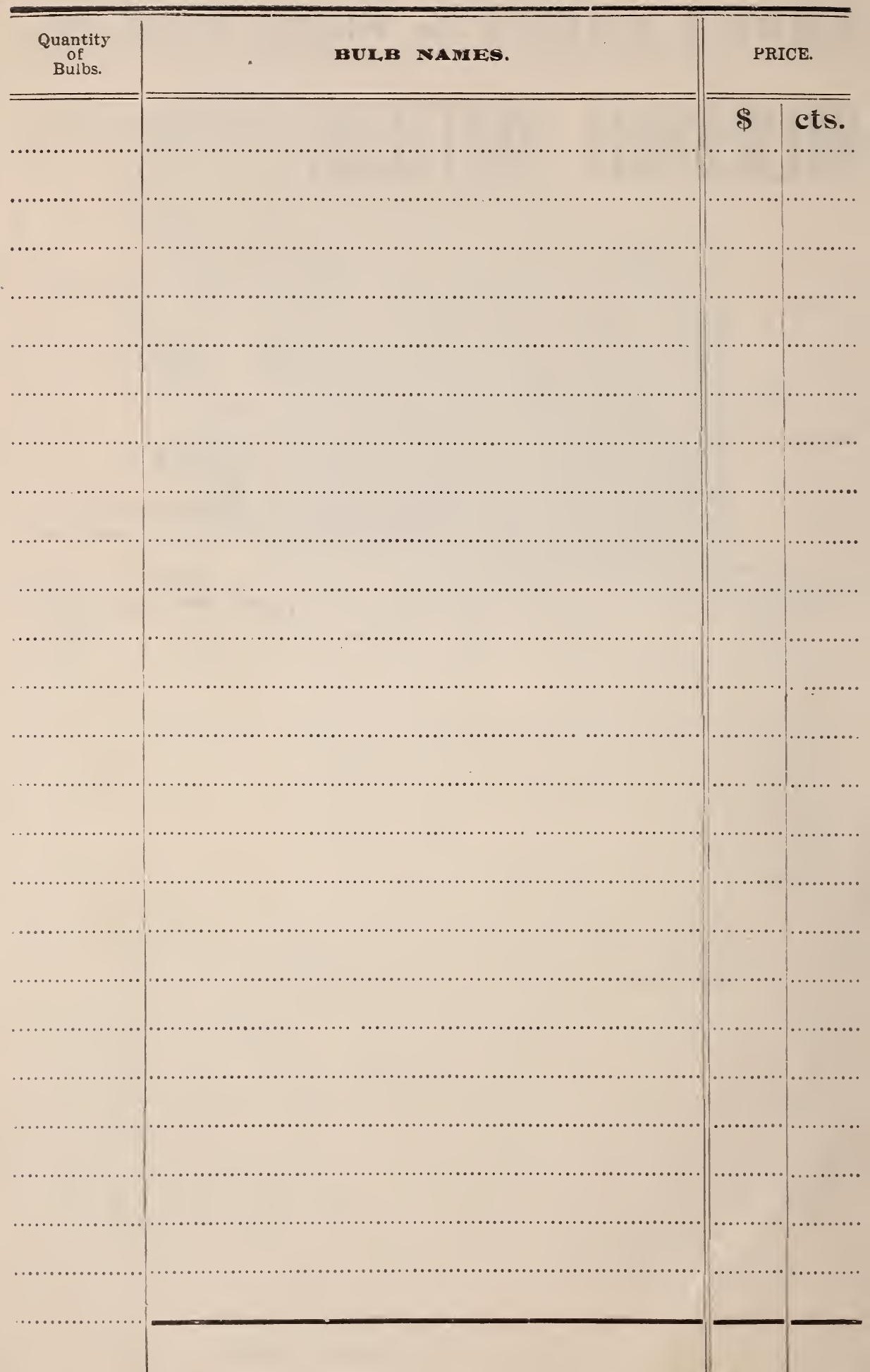



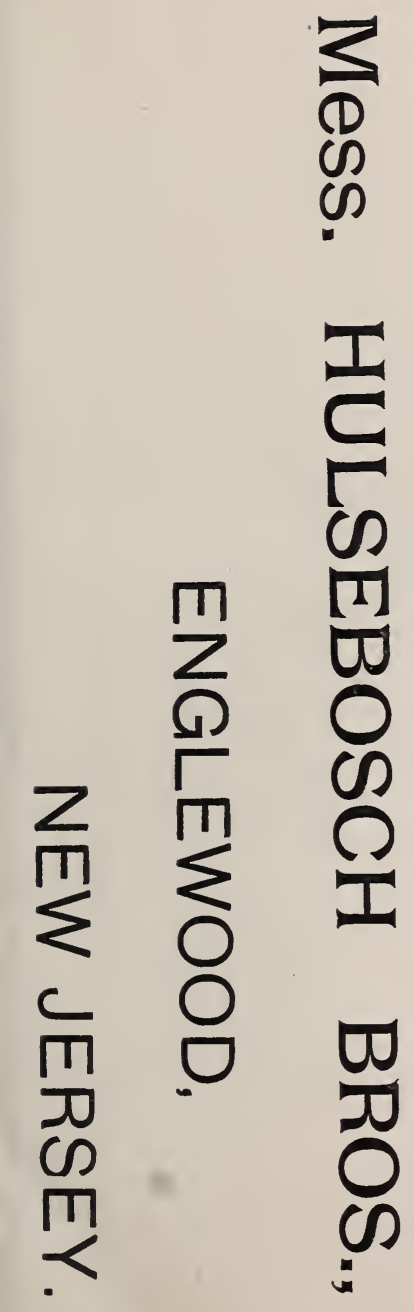

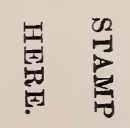





\section{Strong Flowering Shrubs}

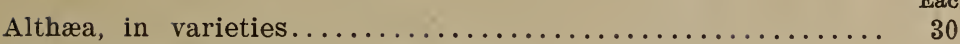

Per $r_{d}$ oz.

Amygdalis pumila alba......................... 30

300

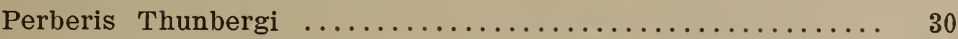

300

300

300

250

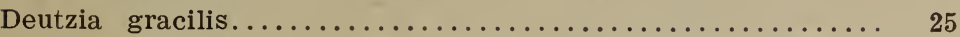

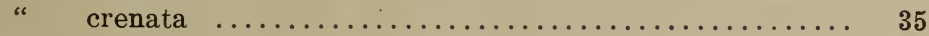

350

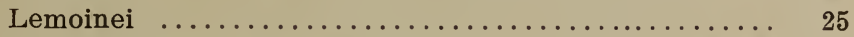

250

300

300

200

300

600

600

200

1000

750

300

300

300

300

300

300

300

300

250

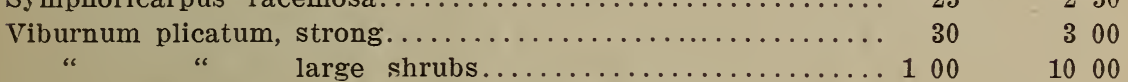

CLIMBING PLANTS, in variety................. $35 \quad 350$

\section{Hardy Herbaceous Perennials}

Achillea ptarmica fl. pl.

The Pearl.

Aquilegia chrysantha.

Aster alpinus.

Campanula Mariesii.

Coreopsis grandiflora. lancelolata.

Gaillardia grandiflora.

Gypsophila paniculata.

Helianthus multiflorus.

Hollyhock, double varieties.

Lathyrus latifolia (perennial pea), scarlet.
Lathyrus latifolia (perennial), pure white.

Lychnis chalcedonica.

Papaver bracteatum, scarlet.

Phlox decussata, in sorts.

" " in fine mixtures.

Platycodon grandiflora.

Sedun, in variety.

Rudbeckia, Golden Glow.

maxima.

Schizostylis coccinea.

Tritoma uvaria.

Any of the above Herbaceous plants, 15 c. each; $\$ 1.50$ per doz.; $\$ 12.00$ per 100 . 
HULSEBOSCH B R O T H ER S 